\title{
Zoophilia as an Early Sign of Psychosis
}

\author{
Vinka Lesandrić ${ }^{*}$, Ivona Orlović ${ }^{2 *}$, Vjekoslav Peitl ${ }^{3}$, Dalibor \\ Karlović ${ }^{3}$ \\ ${ }^{1}$ Department of psychiatry, County General Hospital Vinkovci, Vinkovci, Croatia, ${ }^{2}$ Institute \\ of Public Health, Međimurje County, Čakovec, Croatia, ${ }^{3}$ Department of psychiatry, Sestre \\ milosrdnice University Hospital Center, Zagreb, Croatia
}

*Both authors have contributed equally to this work.

\begin{abstract}
Zoophilia is a disorder of sexual preference that is characterised by sexual fantasies or behaviours that include animals. Zoophilia is more common in comorbidity with other paraphilias. When reviewing scholarly publications, a small number of articles has been found that connect zoophilia, and other psychiatric disorders, and they are shown here. Out of the seventeen known to us isolated cases of patients with zoophilia in comorbity with other psychiatric disorders, nine are noted with zoophilia and psychosis. Precisely in those patients, and also in the case of our patient that we described here, we can speak of zoophilic behaviour as one of the signs of psychosis, although keeping in mind the small sample and the unreliability of data, it is hard to state that zoophilia is an early, or any other sign of psychosis. Considering that in our case zoophilia presented as an early sign of the psychotic process, it is for us to conclude how during noticing of such sexually deviant behaviour it is important to pay attention to all the other psychopathology as to get an insight into the possible start or exacerbation of the psychotic process in order for the treatment to be more directional.
\end{abstract}

Key words: zoophilia, psychosis, schizophrenia, paraphilia

Copyright $@ 2017$ KBCSM, Zagreb

e-mail: alcoholism.kbcsm@gmail.com•www.http//hrcak.srce.hr/acoholism

\section{Introduction}

Zoophilia is a disorder of sexual preference that is characterised by sexual fantasies or behaviours that include animals [1]. Although sexual contact between a man and an animal has been described since biblical

\section{Correnspodence to: Dalibor Karlović}

Department of Psychiatry, Sestre milosrdnice University Hospital Center, Vinogradska cesta 29, 10000 Zagreb, Ctoatia email: dalibor.karlovic@gmail.com times, zoophilia as a mental disorder is first classified in the third edition of the Diagnostic and statistic manual for mental research (DSM-III) [2]. In the last edition of DSM5 zoophilia is classified under the category "Other specified paraphilic disorder". This category is applied for clinical pictures where dominant symptoms cause clinically significant distress or impairment in social, occupational, or other important areas of functioning, but do not meet the full criteria for any 
of the disorders in the paraphilic disorders diagnostic class. With the above mentioned, it is important to meet the time criteria of at least six months of recurrent and intense sexual arousal involving animals. Therefore, paraphilia is a necessary but not a sufficient condition for having a paraphilic disorder, and a paraphilia by itself does not necessarily require clinical intervention until it causes distress or impairment to the individual or risk of harm to others [3]. According to the other most acknowledged diagnostic guidelines, zoophilia is classified into "other disorders of sexual preference" [4]. In the recent literature there are several articles where authors tried to classify zoophilia to help its easier diagnosis and treatment. For the sake of easier diagnosis, Aggrawal and associates, in 2011, have offered a classification of zoophilia in ten categories, which among the others include sexual fantasies about animals, occasional sexual relations with animals and exclusive sexual relations with animals [5].

When talking about the etiology and patophisiology of paraphilia, all the information leading to now suggest an influence of psychosocial and neurobiological factors for the formation of deviant sexual behaviour. Psychological factors which are though to be most important are family violence, dysfunctional family relations, and sexual abuse in childhood. When talking about the neurobiological side, endocrine function in pedophilia research has shown an elevated response of luteinisic hormone $(\mathrm{LH})$ to stimulation of the luteinisic releasing hormone $(\mathrm{LRH})$ or gonadotropin releasing hormone (GRH) [6], which could also be present in zoophilia, but has not been decisively confirmed when taken in consideration a relatively rare incidence of this paraphilia. Furthermore, Casanova and associates have come to a closer approach to the patoanatomic basis of zoophilia, by a representation of two psychiatric patients with zoophilia, where in both of the patients' post mortem had found atrophy of hippocampal pyramidal cells. The first case was a man that suffered from hebephrenic schizophrenia, and the second case was a man that suffered from a bipolar affective disorder and chronic alcoholism. In both cases alongside zoophilia, records show incidence of other paraphilia [7].

Some of the recent research suggest a higher incidence of zoophilia in men, persons with mental retardation, poor social skills and lower levels of education, as well as a higher incidence of zoophilia in people from rural areas, especially among those who work with animals [8]. However, there have been contrary findings, like an internet research on a sample of 82 men and 11 women, which resulted in more common frequency of zoophilia with people of higher education levels and average functioning in society [9]. According to a research by Abel and associates, conducted on 561 men treated for paraphilia, it has been found that certain respondents with zoophilia had comorbidly manifested other paraphilia, while at the same time other psychiatric disorders have not been researched apart from disorders od sexual preference and their representation [10].

\section{Zoophilia and other psychiatric disorders}

Some of the research has tried to answer the question of how much zoophilia is present in psychiatric patients. One of the most interesting observations in that direction comes from a research by Alvarez and Freinhar, who have researched the frequency of zoophilia in an experimental group of 20 
randomly chosen psychiatric patients (with diagnosis of schizophrenia, organic brain syndrome, affective disorders, addiction, and borderline personality disorders) and two control groups (of 20 internal medicine patients and 20 healthy medical workers). The research have shown no occurrence of zoophilia in the control groups, and a 30\% presence of zoophilia in psychiatric patients, but no zoophilia has been specified present in working with individual diagnosis [11]. Bernard and associates deem significant the occurrence of zoophilia among the patients with schizophrenia, but state that there is not enough epidemiological research of representation of paraphilia in the population of psychiatric patients [12]. However, crosssectional study of sexual problems in schizophrenia made on a sample of 137 patients suffering from schizophrenia, shows a representation of paraphilic behaviours in $10.2 \%$, mostly connected with psychotic symptoms. Representation of individual paraphilias had not been tested [13]. Medical articles mostly show isolated case studies of zoophilia in comorbity with psychiatric disorders. That is how Lesjak and associates have shown four psychiatric patients with zoophilic behaviour, and who have been treated as personality disorders with mild mental retardation, manic-depressive psychosis, schizophrenia, and depression. Those patients have also had an anamnestic record of alcohol abuse [14]. In his article from 2016, Holoyda gives a representation of two patients with zoophilia, where one had a diagnosis of a depressive disorder and borderline personality disorder, and the other had a schizoaffective disorder and an antisocial personality disorder [15]. Also noted is a case of a sixty year old man with a diagnosis of a bipolar-affective disorder, who has shown paraphilic behaviour, along the zoophilia, in the manic phases of his illness. In that context, it is important to accentuate that hyper sexuality is a common symptom of the manic phase of the bipolar disorder, but none the less, paraphilic behaviour as a part of that disorder is still rare [16]. Also, acute symptoms of other psychiatric disorders can affect the individual's insight, his ability to asses and control impulses, thus increasing the probability of aberrant sexual behaviour [15].

Our case is a young man aged 24 without history of mental illnesses in his family, who has been sent to treatment under a clinical picture of psychosis. He has grown up in a wholesome family, as the youngest of three children. He defines his family relations during his growing up as harmonious, although states his father's authoritative upbringing. His vocation is a mechanical engineering technician, but since his parents have an agricultural trade, he is employed there and has never tried to find a job somewhere else. He is socially coy, makes contact with members of his immediate family, and a few closest friends, and so far has not had an emotional relationship. He states that in the eight grade of elementary school, in the middle of the night, he felt the urge to have a sexual relation with a cow, and had achieved that relation. Current findings show that sexual relations with animals start in the ages between 11 and 14 [17], which coincides with our patient's description. He has not repeated that activity for the next ten years, but had frequent sexual fantasies about sexual relations with a cow, and than repeated the act in June 2016. Then followed a psychotic decompensation. During the patient admission, the patient was of inhibited opinions, the productive side has shown paranoid interpretations of reality events in presentation, as well as 
occasional suicidal thoughts (which he has enshrouded from), his affect was remote, and he himself was anxious and glum. He clearly negates the statement that halucinatory experiences or the feeling of imposition of thoughts have preceeded the sexual act. By the age of 24 , he had not had sexual contacts with humans but gained sexual gratification by performing sexual acts with animals and by fantasizing about animalistic objects. He states his familiy's religious beliefs that lead him to feel guilt, as well as his efforts to resist his urges as a reason why he had not repeated the activity for 10 years. The psychological tests (TN-10, MMPI-201, PIE, W'TC, Machover) showed a lower intellectual efficiency with a suspected start of a deeper, in fact psychotic process. We have found similar results of psychological testing, foremost in the area of lower intellectual functioning and inadequate social behaviour in an article by Satapathy and associates, which described a case of zoophilia of an eighteen year old boy who has, like out patient, lived on a farm, in a rural area, with a family with a large number of children, and who had not been diagnosed with another psychiatric comorbity alongside zoophilia [18]. Lastly, Amoo and associates have described a case of a twenty year old man affected with schizophrenia with premorbid zoophilic orientation and antisocial personality traits, who had due to the symptoms of endogenic psychotic process recurred zoophilic behaviour. Like in our patient, there were reports of paranoid interpretation of reality and remote affect [19].

\section{Discussion}

When reviewing scholarly publications, a small number of articles has been found that connect zoophilia, and other psychiatric disorders, and they are shown here. Out of the seventeen known to us isolated cases of $\mathrm{pa}$ tients with zoophilia in comorbity with other psychiatric disorders, nine are noted with zoophilia and psychosis. Precisely in those patients, and also in the here described case, we can speak of zoophilia as one of the signs of psychosis, although keeping in mind the small sample and the unreliability of data, it is hard to state that zoophilia is an early, or any other sign of psychosis. Considering that in our case zoophilic behaviour showed as an early sign of the psychotic process, it is for us to conclude how during noticing of such sexually deviant behaviour it is important to pay attention to all the other psychopathology as to get an insight into the possible start or exacerbation of the psychotic process in order for the treatment to be more directional. Also, the connection between other psychiatric disorders, and paraphilic behaviour opens a lot of space for future research, taking into consideration that sexual problems and fantasies in psychiatric patients are very common, but rarely defined. We believe that during the psychiatric examination extra care should be given to the questions about possible sexual deviations, as well as general sexual functioning.

\section{Acknowledgements}

None

\section{Conflict of interest}

None to declare 


\section{References}

1. World Health Organisation. The ICD-10 classification of Mental and Behavioural Disorders. Diagnostic criteria for Research. Geneva: WHO; 1992.

2. Aggrawal A. References to paraphilias and sexual crimes in the Bible. J Forensic Leg Med 2009;16:109-114.

3. Američka psihijatrijska udruga. Dijagnostički i statistički priručnik za duševne poremećaje. Peto izdanje. Jastrebarsko: Naklada Slap, 2014.

4. Hrvatski zavod za javno zdravtsvo. Međunarodna klasifikacija bolesti i srodnih zdravstvenih problema. Drugo izdanje. Zagreb, Medicinska naklada, 2012.

5. Aggrawal A. A new classification of zoophilia. J Forensic Leg Med. 2011;18:73-78.

6. Labelle A, Bourget D, Bradford JMW, et al. Familial Paraphilia: A Pilot Study with the Construction of Genograms. ISRN Psychiatry, 2012.

7. Casanova MF, Mannheim G, Kruesi M. Hippocampal pathology in two mentally ill paraphiliacs. Paychiatry Res. 2002;115:79-89.

8. Earls CM, Lalumiere ML. A Case Study of Preferential Bestiality. Arch Sex Behav. 2009;38:605-9.

9. Miletski H. Zoophilia: Another Sexual Orientation? Arch Sex Behav. 2017;46:39-42.

10. Abel GG, Becker JV, Cunniham-Rathner J, et al. Multiple paraphilic diagnoses among sex offenders. Bull Am Acad Pschiatry Law. 1988;16:153-68.
11. Alvarez WA, Freinhar JP. A prevalence study of bestiality (zoophila) in psychiatric in-patients, medical in-patients, and psychiatric staff. Int J Psychosom. 1991;38;45-7.

12. Bernard M, Clancy B, et al. Human Sexuallity for Health Professionals. Philadelphia: WB Saunders Company; 1978.

13. Harley EWY, Boardman J, Craig T. Sexual problems in schizophrenia: prevalence and characteristics. A cross sectional survey. Soc Psychiatry Psychiatr Epidemiol. 2010;45:759-66.

14. Lesjak B, Bogadi M, Tošić G. Zoofilija u komorbiditetu s drugim psihijatrijskim poremećajima. Socijalna psihijatrija. 2004;32:160-4.

15. Holoyda B. Bestiality in Forensically Committed Sexual Offenders: A case series. J Forensic Sci. 2016.

16. Mendhekar DN, Mehta R. Mania associated with multiple paraphilias. Indian J Med Sci. 2006;60:289.

17. Williams CJ, Weinberg MS. Zoophilia in men: A study of sexual interests in animal. Arch Sex Behav. 2003;32:523-35.

18. Satapathy S, Swain R, Pandey V, Behera C. An adolescent with bestiality behaviour: psychological evaluation and community health concerns. Indian J Community Med. 2016;41:23-26.

19. Amoo G, Abayomio O, Olashore A A. Zoophilic recidivism in schizophrenia. A case report. Afr J Psychiatry. 2002;15:223-5.

\section{Zoofilija kao rani znak psihoze}

Sažetak - Zoofilija je poremećaj seksualne sklonosti kojeg karakteriziraju ponavljajuće seksualne fantazije ili ponašanja koja uključuju životinje. Zoofilija se češće javlja u komorbiditetu s drugim parafilijama. U preglednoj literaturi je rijetko zabilježen komorbiditet zoofilije i drugih psihijatrijskih poremećaja, uglavnom su to izolirani prikazi slučajeva, a isti su prikazani u našem radu. Od sedamnaest nama poznatih izoliranih slučajeva pacijenata sa zoofilijom u komorbiditetu s drugim psihijatrijskim poremećajima, zabilježeno je njih devet sa zoofilijom i psihozom. Upravo kod tih pacijenata, pa onda i u slučaju našeg pacijenta koji smo opisali, možemo govoriti o zoofiliji kao o jednom od znakova psihoze, iako je s obzirom na mali uzorak i nepouzdanost podataka teško moguće tvrditi kako je zoofilija rani ili bilo kakav drugi znak psihoze. S obzirom da se u našem slučaju zoofilija prezentirala kao rani znak psihotičnog procesa ostaje nam za zaključiti kako je prilikom uočavanja takvog seksualno devijantnog ponašanja ipak potrebno obratiti pažnju i na ostalu psihopatologiju ne bi li se dobio uvid u mogući početak ili egzacerbaciju psihotičnog procesa kako bi i liječenje bilo usmjerenije.

Ključne riječi - zoofilija, psihoza, shizofrenija, parafilija 